\title{
IFS
}

\section{WHAT DO THE CHILD POVERTY TARGETS MEAN FOR THE CHILD TAX CREDIT? AN UPDATE}

Mike Brewer 


\title{
What do the child poverty targets mean for the child tax credit? An update
}

\author{
Mike Brewer ${ }^{*}$ \\ Institute for Fiscal Studies
}

\section{Summary}

The government has a target for child poverty to fall to 3.1 million by 2004-05, measured by the number of children in households with less than $60 \%$ median income after housing costs. The latest data showed that 3.8 million children (30\% of children in Britain) were in poverty in $2001-02$ on this definition. To help achieve the target, increases to means-tested benefits and tax credits need to take effect in April 2004, and therefore need to be announced in the forthcoming Pre-Budget Report.

New calculations suggest that around $£ 1$ billion of further spending on the child tax credit might be needed to meet the child poverty target. Increases in other benefits or tax credits could also reduce child poverty, but at greater cost. But if the government chooses not to increase support for families with children in 2004-05, then real spending on child-contingent support in the tax and benefit system will still have increased by over $50 \%$ since 1997 , and child poverty in 2004-05 should be at its lowest level since 1989.

The government is still deciding what definition of child poverty it wishes to target in the longer term. If it wishes to reduce further child poverty measured under its current definition, then this will require the means-tested benefits and tax credits received by poor families with children to rise faster than the rate of inflation in the absence of helpful economic or demographic changes, such as more parents working. However, continuing to target a poverty measure defined exclusively in terms of incomes may skew the policy response excessively towards tax credit and means-tested benefits changes, and away from improving public services for children which might have a greater impact

\footnotetext{
"Mike Brewer is a senior research economist at IFS. This Briefing Note updates the analysis in M. Brewer, A. Goodman and A. Shephard, How Has Child Poverty Changed under the Labour Government? An Update, IFS Briefing Note 32, 2003, http://www.ifs.org.uk/inequality/bn32.pdf, and M. Brewer and G. Kaplan, 'What do the child poverty targets mean for the child tax credit?', in R. Chote, C. Emmerson and H. Simpson (eds), The IFS Green Budget: January 2003, IFS Commentary 92, 2003, http://www.ifs.org.uk/gb2003/ch4.pdf. Support from the ESRC-funded Centre for the Microeconomic Analysis of Public Policy (grant no. M535255111) is gratefully acknowledged. The author is very grateful to Robert Chote and Alissa Goodman for helpful discussions and comments. The Households Below Average Income and the Family Resources Survey data-sets are used with permission of the Department for Work and Pensions, which bears no responsibility for the views expressed here.
} 
on their well-being over the longer term. By way of example, the extra spending that we think is needed for the government to meet its target for 2004-05 would pay for the current Sure Start programme - which aims to improve the health and well-being of families and children aged under 5 in disadvantaged areas - to be doubled in size.

\section{Child poverty since 1996-97 and the government's target for 2004- 05}

In March 1999, the Prime Minister announced the ambition to 'eradicate child poverty within a generation'. Subsequently, the Treasury set out further objectives: to eradicate child poverty by 2020, to halve it by 2010 and to reduce it by a quarter by $2004 .^{1}$

The government has made clear that 'the target for 2004 will be monitored by reference to the number of children in low-income households by 2004-05. Low-income households are defined as households with income below $60 \%$ of the median, as reported in the Households Below Average Income (HBAI) statistics ... Progress will be measured against the 1998/9 baseline figures and methodology'.

The wording of the government's target does not specify whether income is to be measured before housing costs (BHC) or after housing costs have been deducted (AHC), nor whether self-employed households are to be included. In practice, ministers' statements have tended to focus on progress on the AHC measure including the self-employed. As there were 4.2 million children in poverty in 1998-99 on this definition, there will need to be no more than 3.1 million children in poverty in 2004-05 to meet the target. ${ }^{3}$

\footnotetext{
${ }^{1}$ The target for 2004 is set out in HM Treasury, Spending Review 2000: Public Service Agreements 2001-04, Cm. 4808, Stationery Office, London, 2000, http://www.hmtreasury.gov.uk/Spending_Review/Spending_Review_2000/Spending_Review_Report/spend sr00 repindex.cfm. The target was initially a joint Public Service Agreement (PSA) target for HM Treasury and the former Department of Social Security accompanying the 2000 Spending Review, and was carried forward in the 2002 Spending Review. In this, and the rest of the chapter unless otherwise specified, 'child' means 'dependent child' - a child under 16, or under 19 and in full-time education.

${ }^{2}$ HM Treasury, Autumn Performance Report 2002, Cm. 5665, Stationery Office, London, 2002, www.hm-treasury.gov.uk/about/departmental_reports/Autumnreport_2002.cfm. In the HBAI statistics, children are considered poor depending on the total income of the household in which they live. The median household is the one for which half the rest of the population has an income higher than it does and half has an income lower.

${ }^{3}$ The Treasury has said that the PSA wording implies that the 'target for 2004-05 is 3.15 million (AHC) and 2.325 million (BHC)' (see annex A in HM Treasury, Autumn Performance Report 2002, op. cit.). However, it is conventional for all numbers in HBAI to be rounded to the nearest 100,000 , and so our interpretation is that child poverty needs to be 3.1 million for the government to have met its target. This would represent a fall of over a
} 
What has happened to date? Between 1996-97 and 2001-02 (the latest year for which data are currently available), the number of children in households below $60 \%$ of median AHC income fell from 4.4 million to 3.8 million, a decline which is statistically significant from zero. ${ }^{4}$ Measuring poverty BHC, the target level is 2.3 million children, and the government is closer to reaching its target for 2004-05, having seen a decline from 3.1 million in 1998-99 to 2.7 million in $2001-02 .^{5}$ However measured, the fall in child poverty since 1996-97 follows a very long period during which it increased substantially. ${ }^{6}$

\section{What more does the government need to do?}

Work carried out at IFS a year ago gave a central prediction that child poverty would fall to 3.3 million by $2004-05{ }^{7}$ We have updated this work to reflect the extra year's data that have become available since then. Our central conclusions, however, remain unchanged: we predict that the government will narrowly miss its target in 2004, and that spending an extra $£ 1$ billion on the child tax credit by increasing the per-child element by $£ 3$ a week should be sufficient for the government to meet its target. Below, we explain these calculations in more detail.

\subsection{Is the government likely to meet its child poverty target in 2004-05?}

Assessing future levels of child poverty requires us to take a view on the impact of future policy reforms on the incomes of poor families with children, and also on the likely impact of economic and demographic factors on the incomes of poor families and on the median income against which they are to be compared. This is because the government is targeting a relative measure of child poverty rather than an absolute one: whether a household is judged to be poor depends not only on the cash value of its income, but also on how much it has relative to the median household.

quarter of the level in 1998-99, whereas a level of child poverty of 3.2 million in 2004-05 would represent a fall of slightly less than a quarter.

${ }^{4}$ See Brewer, Goodman and Shephard, How Has Child Poverty Changed under the Labour Government? An Update, op. cit.

${ }^{5}$ Poverty is lower when measured BHC than when measured AHC because housing costs are a larger proportion of total expenditure for low-income families with children than for others. Because the government and commentators tend to focus on measuring incomes AHC when thinking about the bottom end of the income distribution, we do so in this Briefing Note.

${ }^{6}$ See Brewer, Goodman and Shephard, How Has Child Poverty Changed under the Labour Government? An Update, op. cit., or P. Gregg, S. Harkness and S. Machin, 'Poor kids: trends in child poverty in Britain, 1968-96', Fiscal Studies, 1999, vol. 20, pp. 163-87.

${ }^{7}$ Brewer and Kaplan, 'What do the child poverty targets mean for the child tax credit?', op. cit. 
It is important not to neglect the impact of wider economic and demographic changes, for two reasons. First, some changes - such as increased employment amongst mothers - will increase the incomes of low-income families with children and directly reduce child poverty. ${ }^{8}$ Secondly, anything that changes median income will directly affect the poverty line.

Unfortunately, accurately forecasting what might happen to the distribution of income by 2004-05 is very difficult. Median household income is affected by numerous factors, including growth in earnings and unearned income, as well as changes in the population, household composition, patterns of employment, tax and benefit policies, and take-up of means-tested benefits and tax credits. To make our forecast, we assume that the population, employment rates and household composition do not change from their 2001-02 values, but that real earnings do change over time. ${ }^{9}$ This rise in real earnings changes the poverty line, and this will tend to worsen child poverty because earnings are a less important source of income for poor households with children than they are for the median household.

Table 1 shows our overall assessment of likely changes in child poverty between 2001-02 and 2004-05. Column 1 shows the actual level of child poverty in 2001-02. Column 2 shows our estimate of the change in child poverty over the following four years arising solely from the government's tax and benefit reforms. ${ }^{10}$ In other words, adjusting suitably for likely price changes over that period, it shows how different child poverty would have been in 2001-02 had the 2004-05 tax and benefit system been in place then. We estimate that these reforms to personal tax and benefits could reduce the number of children in households with incomes below $60 \%$ of the median by 0.7 million.

\footnotetext{
${ }^{8}$ H. Sutherland, T. Sefton and D. Piachaud, Poverty in Britain, Joseph Rowntree Foundation, York, 2003, shows that changes in employment patterns amongst families with children were very important in reducing child poverty between 1996 and 2000.

${ }^{9} \mathrm{We}$ assume that all workers benefit from the actual average real earnings growth until March 2003 , and then from an assumed real earnings growth of $1 \%$ after that point. This is relatively low historically: the average between 1998 and 2001 was $2.3 \%$, for example. Our main results do not change, to the degree of accuracy shown here, if we assume that average real earnings growth between $2003-04$ and $2004-05$ is $0 \%$ or $2.3 \%$, rather than $1 \%$, partly because the government has committed to increasing the per-child element of the child tax credit in line with growth in average earnings. We also make assumptions about future growth in rents, council tax and water charges between 2003 and 2004 (available on request).
}

\footnotetext{
${ }^{10}$ This change is actually calculated from an estimate of child poverty in 2001-02 generated by our model, which simulates tax payments and benefit entitlements rather than using data on actual tax payments and benefit receipts as the HBAI methodology does. Our model gives numbers of children in poverty of 2.3 million ( $50 \%$ median), 3.8 million ( $60 \%$ median) and 4.9 million ( $70 \%$ median). As these starting levels are only fractionally different from the HBAI estimates, the calculated changes (produced by our model) can reasonably be applied to the actual HBAI figures.
} 
Table 1. Possible changes in child poverty (AHC), 2001-02 to 2004-05 (millions of children)

\begin{tabular}{|c|c|c|c|c|c|}
\hline Poverty line & $\begin{array}{c}(1) \\
\text { Actual child } \\
\text { poverty, } \\
\text { 2001-02, } \\
\text { HBAI }\end{array}$ & $\begin{array}{c}(2) \\
\text { Change due to } \\
\text { tax and benefit } \\
\text { reforms, } \\
2001-02 \text { to } \\
2004-05\end{array}$ & $\begin{array}{c}\text { (3) } \\
\text { Change due to } \\
\text { earnings } \\
\text { growth, } \\
\text { 2001-02 to } \\
2004-05\end{array}$ & $\begin{array}{c}(4) \\
\text { Total change, } \\
2001-02 \text { to } \\
2004-05\end{array}$ & $\begin{array}{c}(5) \\
\text { Estimate for } \\
\text { 2004-05 using } \\
\text { HBAI values } \\
\text { for 2001-02 }\end{array}$ \\
\hline $50 \%$ median & 2.5 & -0.9 & +0.3 & -0.6 & 1.8 \\
\hline $60 \%$ median & 3.8 & -0.7 & +0.2 & -0.5 & 3.3 \\
\hline $70 \%$ median & 4.9 & -0.5 & +0.1 & -0.4 & 4.6 \\
\hline
\end{tabular}

Notes: Column $4=$ column $2+$ column 3 ; column $5=$ column $1+$ column 4 . Numbers are rounded to the nearest 100,000, as is the custom in HBAI, but this should not be interpreted as a measure of accuracy. Changes are based on unrounded numbers, and numbers may not sum due to rounding. Column 3 uses actual growth in average earnings between April 2001 and April 2003, and an assumed annual growth of 1\% between April 2003 and April 2004; the main results do not change, to the degree of accuracy shown here, if we assume that average real earnings growth between April 2003 and April 2004 is $0 \%$ or $2.3 \%$, rather than $1 \%$. The bootstrapped estimated standard error for the fall in child poverty measured as $60 \%$ of median income in column 4 is around 40,000; this only reflects sampling error and not any other source of error in our calculations.

Source: Author's calculations from IFS tax and benefit model, TAXBEN, using 2001-02 Family Resources Survey, except column 1, which is from Department for Work and Pensions, Households Below Average Income 1994/5 to 2001/02, CDS, Leeds, 2003.

Column 3 gives our forecast of the impact of three years of real earnings growth, pushing around 0.2 million children back below the new, higher poverty line. Column 4 shows the predicted overall impact of both policy changes and earnings growth. Applying this to the actual child poverty data in the first column gives us the predicted level in 2004-05 (column 5). The bottom line is that child poverty is likely to reach 3.3 million children in 200405 (AHC), slightly adrift of the government's target of 3.1 million.

For comparison, Table 1 also shows estimates for other poverty lines the government could have chosen relative to median income measured after housing costs.

The estimates in Table 1 have accounted for likely real earnings growth between 2001-02 and 2004-05. But other things that affect child poverty could change over this period, such as the number of families and children, the employment rates of parents and other adults, and take-up rates for meanstested benefits and tax credits. In addition, our assumptions may be incorrect: for example, earnings growth may differ between low-paid and high-paid workers. This means that there is a considerable degree of uncertainty around the estimates in Table 1. But, on our central forecast, unless the economic and demographic changes that we have not modelled reduce child poverty, the government will need to spend more to hit its after-housing-costs child poverty target for 2004-05. 
This Briefing Note updates work carried out in late 2002 (see Brewer and Kaplan, 'What do the child poverty targets mean for the child tax credit?', op. cit.). That work also gave a central prediction that child poverty would fall to 3.3 million by $2004-05$. There are two important differences between our new estimates (in Table 1) and our old work (table 4.1):

- We now know that child poverty, recorded by HBAI, fell by 100,000 between 2000-01 and 2001-02 (column 1).

- Our estimate of the impact of policy reforms yet to be reflected in the actual HBAI data fell by an exactly offsetting 100,000 , from 800,000 to 700,000 (column 2).

In other words, the decline in child poverty between 2000-01 and 2001-02 was small, but this was because there were few important anti-child-poverty reforms in that year compared with those in 2002-03 and 2003-04. We have also lowered our assumption of earnings growth between April 2003 and April 2004 , but this has no effect on the results, to the level of accuracy presented here.

Other researchers have also attempted to forecast levels of child poverty using a similar methodology to us. Table 13 in Sutherland, Sefton and Piachaud, Poverty in Britain, op. cit., reports work that forecasts child poverty in 2003-04 to be $3,250,000$. The authors conclude from this that 'the number of children in poor households will be one third below its 1997 level by 2004 before housing costs are taken into account, and a quarter lower after housing costs are deducted. This means that the Government should meet its short-term target, unless other factors, such as employment, take a turn for the worse'. Their conclusion that the government is already on course to hit the target reflects both a marginally more optimistic assessment of the likely path of child poverty under current policies and a slightly less challenging numerical interpretation of the target than we make.

\subsection{What tax and benefit changes could the government make?}

The structure of the system of support for families with children means that the government has three ways to redistribute income exclusively to families with children:

- child benefit, which will be of assistance to all families with children, regardless of their income; 
- the family element of the child tax credit, which will direct money to all but the richest $10 \%$ of families, in a way that does not vary with income or number of children;

- the child element of the child tax credit, which will direct money to the poorest half of families with children, and will be of more help to large families than to smaller ones.

Previous IFS work has confirmed the intuition that, for a given level of expenditure, increasing the per-child element of the child tax credit will have a larger direct impact on poverty than increasing the family element or increasing child benefit. ${ }^{11}$ For this reason, we have focused on modelling the effect of changes to the per-child element.

The government has promised to increase the per-child element in line with average earnings growth in April 2004 and April 2005. If the government uses the current headline change in the average earnings index to uprate the perchild element, then it would rise from $£ 1,445$ a year to $£ 1,495$ in April 2004. ${ }^{12}$ This is a very small increase in child-related payments compared with those experienced on average between 1996 and 2003. The impact on child poverty of this increase was taken into account, though, in the calculations in Table 1. So, to understand what more needs to be done, we have estimated the number of children that would be taken out of poverty by various policies, all assumed to take effect in April 2004 (see Table 2): ${ }^{13}$

- increases in the per-child element of the child tax credit of $£ 3$ a week and $£ 5$ a week above the rise in line with earnings growth;

- increases in all adult allowances in income support by $£ 2.50$ a week;

- introduction of a new premium into the child tax credit to be paid to families with three or more children; the premium would be worth $£ 845$ a year to all families with three or more children with joint annual incomes below $£ 50,000$;

\footnotetext{
${ }^{11}$ See section 4.4 in Brewer and Kaplan, 'What do the child poverty targets mean for the child tax credit?', op. cit.

${ }^{12}$ This assumes that the tax credit is rounded to the nearest $£ 5$. The annual change in the headline rate of the average earnings index in September 2003 was 3.6\% (see http://www.statistics.gov.uk/pdfdir/lmsuk1103.pdf) and inflation in the year to September 2003 was $2.8 \%$ (http://www.statistics.gov.uk/downloads/theme economy/RP04.pdf), meaning that real earnings growth in the year to September 2003 was only $0.8 \%$.

${ }^{13}$ For all changes except the increase in the working tax credit, we increase allowances and premiums in housing benefit and council tax benefit to ensure that families receiving these benefits gain by the full amount.
} 
- increase in the working tax credit for families with children by $£ 11.75$ a week.

To allow for a fair comparison, all of these policies except the increase in the per-child element of the child tax credit of $£ 5$ a week cost roughly the same: $£ 1$ billion a year.

Each of these policy changes targets a different group:

- Increases in the per-child element of the child tax credit benefit the poorest half of families with children. An increase of $£ 3$ a week would bring the total financial support for the first child in families with incomes under $£ 13,200$ to around $£ 2,990$ a year (current prices). ${ }^{14}$ By contrast, adults aged 25-59 are entitled to $£ 2,840$ a year in income support, and adults aged under 25 are entitled to just $£ 2,250$. By increasing the amount of tax credit income that is subject to the $37 \%$ tax credit taper, increases in the per-child element would reduce the financial incentive for some low-paid parents to increase their earnings beyond $£ 13,200$.

- Increases in income support benefit the poorest individuals in society. Under the current structure of income support, parents have the same entitlements as adults without children with the same incomes. We have assumed that the government would not change this, and so our proposed reform benefits all adults, including the over-60s, on income support (and housing benefit and council tax benefit) whether or not they have children. This makes this reform much more expensive than the other changes for a given increase in the incomes of families with children. The reform would slightly reduce the financial incentive for families to have one adult in work.

- The premium for families with three or more children would provide a substantial increase in income for these families. A third of all children in Britain and $45 \%$ of children in poverty live in households with three or more children, and recent research has suggested that families with three or more children are particularly disadvantaged. ${ }^{15}$ Because we have assumed that the premium would operate in the same way as the family premium in the child tax credit, it would be worth as much to families with three or more children on $£ 50,000$ as it would be to the poorest. The impact on work incentives would be negligible.

\footnotetext{
${ }^{14}$ The sum of the family premium and the child element of the child tax credit and child benefit in 2003-04 is $£ 2,835$. The child elements of the child tax credit begin to be tapered away at incomes of around $£ 13,230$ (see M. Brewer, The New Tax Credits, IFS Briefing Note 35, 2003, http://www.ifs.org.uk/taxben/bn35.pdf).

${ }^{15}$ L. Adelman, S. Middleton and K. Ashworth, Britain's Poorest Children: Severe and Persistent Poverty and Social Exclusion, Save the Children, London, 2003.
} 
- Of the poorest 3.5 million families with children that currently receive more than the family premium of the child tax credit, those who have an adult in work will benefit from a rise in the working tax credit, but the poorest families who do not work will gain nothing. ${ }^{16}$ Families with someone in work and earning less than around $£ 13,000$ would gain the full $£ 610$. The reform would improve the financial incentive for families with children to have one adult in work, but it would reduce the financial incentive for some low-paid parents to increase their earnings and for some second earners in couples to move into work.

Table 2. Effect of possible increases in per-child element of the child tax credit in April 2004

\begin{tabular}{|c|c|c|c|}
\hline $\begin{array}{l}\text { Increase in per-child element of } \\
\text { child tax credit in April } 2004\end{array}$ & $\begin{array}{l}\text { Annual per-child } \\
\text { child tax credit } \\
\text { rate, } 2004 \text { prices }\end{array}$ & $\begin{array}{c}\text { Number of children } \\
\text { taken out of poverty } \\
(60 \% \text { median income AHC) }\end{array}$ & $\begin{array}{c}\text { Cost per } \\
\text { year, 2004 } \\
\text { prices } \\
\text { (£ million) }\end{array}$ \\
\hline $\begin{array}{l}\text { Average earnings growth }+£ 155 \\
\text { a year (£3 p.w.) }\end{array}$ & $£ 1,650$ & 240,000 & 1,040 \\
\hline $\begin{array}{l}\text { Average earnings growth }+£ 260 \\
\text { a year ( } £ 5 \text { p.w.) }\end{array}$ & $£ 1,755$ & 395,000 & 1,750 \\
\hline \multicolumn{4}{|l|}{$\begin{array}{l}\text { Other possible changes } \\
\text { in April } 2004\end{array}$} \\
\hline $\begin{array}{l}\text { Income support adult allowances } \\
\text { increased by } £ 2.50 \text { p.w. }\end{array}$ & $£ 1,495$ & 55,000 & 1,040 \\
\hline $\begin{array}{l}\text { Child tax credit premium of } £ 845 \\
\text { a year for families with three or } \\
\text { more children ( } £ 16.25 \text { p.w.) }\end{array}$ & $£ 1,495$ & 210,000 & 1,010 \\
\hline $\begin{array}{l}\text { Working tax credit for families } \\
\text { with children increased by } £ 610 \text { a } \\
\text { year ( } £ 11.75 \text { p.w.) }\end{array}$ & $£ 1,495$ & 150,000 & 1,040 \\
\hline \multicolumn{4}{|c|}{$\begin{array}{l}\text { Notes: 'Number of children taken out of poverty' is rounded to the nearest 5,000 and 'Cost per year' is } \\
\text { rounded to the nearest } £ 10 \text { million, but these should not be interpreted as measures of accuracy. The } \\
\text { poverty line was allowed to move if the reform altered median household income. Except for the } \\
\text { increase in the working tax credit, housing benefit and council tax benefit allowances and premiums } \\
\text { are adjusted so that families on these benefits gain by the full amount stated. } \\
\text { Source: Author's calculations from IFS tax and benefit model, TAXBEN, using 2001-02 Family } \\
\text { Resources Survey. }\end{array}$} \\
\hline
\end{tabular}

To reduce child poverty from 3.3 million to the target level of 3.1 million, our estimates suggest that the per-child element of the child tax credit would need to be increased by around $£ 3$ a week (or $£ 155$ a year) above the rise in line with earnings growth that has already been promised. This would cost approximately $£ 1$ billion (in 2004 prices). ${ }^{17}$ An increase in the per-child credit

\footnotetext{
${ }^{16}$ The fact that the per-child elements of the child tax credit and the working tax credit are tapered away consecutively as income rises means that increases in the working tax credit will benefit not just families currently receiving some working tax credit but also those receiving any of the per-child element of the child tax credit.

${ }^{17}$ Just as for the key results in Table 1, the new data that have become available in the past 12 months have not substantially altered our estimates of the impact of increases in the child tax
} 
of $£ 5$ a week (or $£ 260$ a year) would reduce child poverty by 0.4 million and should mean that the government comfortably meets its target. None of the other policies is as effective at reducing child poverty as increases in the perchild element of the child tax credit, for a given level of government expenditure: a premium for families with three or more children comes the closest, and the income support rise is the least well targeted at reducing child poverty.

\section{Figure 1. Distributional effects of different increases in child-related benefits and tax} credits in April 2004

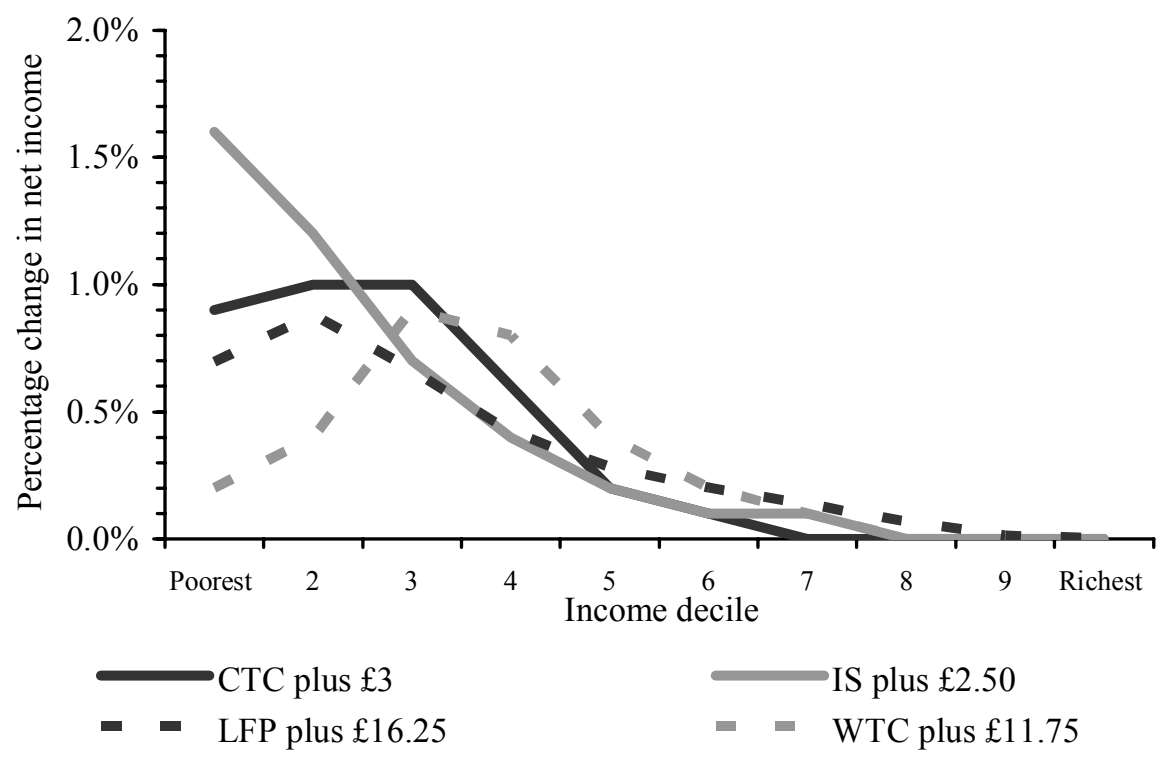

Notes: The graph shows gains in addition to gains from the increase to the per-child element of the child tax credit in line with earnings growth in April 2004 to which the government is already committed. Income deciles are derived by dividing all families (with and without children) into 10 equally sized groups according to income adjusted for family size using the McClements equivalence scale. Decile 1 contains the poorest tenth of the population, decile 2 the second poorest and so on, up to decile 10, which contains the richest tenth. CTC: per-child element of child tax credit; IS: income support; LFP: a new child tax credit premium for families with three or more children; WTC: working tax credit for people with children. See text for details of changes.

Source: IFS tax and benefit model, TAXBEN, based on 2001-02 Family Resources Survey.

All four policies would be progressive, in that they would benefit poor households by more than rich households, as shown in Figure 1. The graph also shows that:

- The bottom decile gains less than the second and third deciles under the three measures that benefit only families with children; this is because there are relatively few families with children in the first decile. For the same reason, the increase in income support is the most progressive reform

credit on child poverty compared to those of Brewer and Kaplan, 'What do the child poverty targets mean for the child tax credit?', op. cit. 
because it benefits poor adults without children, who tend to be in the poorest decile.

- Compared with the $£ 3$-a-week increase in the child tax credit, the gains from the increase in the working tax credit are very low in the first two deciles and higher in deciles three and four. This is because families with children need to have an adult working 16 or more hours to benefit from the reform, and such families are not the poorest in society.

- The reform that benefits the richer half of society the most is the premium for families with three or more children; this is because we have assumed that all families with three or more children with annual incomes up to $£ 50,000$ gain by the same amount.

\subsection{Conclusions}

The government is likely to miss its child poverty target for 2004-05 unless it announces extra financial transfers to families with children in the 2003 PreBudget Report. The most cost-efficient measure would be an increase in the per-child element of the child tax credit of at least $£ 3$ a week. Other changes could also reduce child poverty, but at greater cost, although with different and perhaps preferable - impacts on the distribution of income and work incentives.

\section{Measuring success: confidence intervals and child poverty}

We will not know whether the government has met its target until early 2006, when official figures on child poverty for 2004-05 are due to be published in the annual Households Below Average Income publication. ${ }^{18}$ These figures are actually estimates derived from a household survey of around 30,000 families in Great Britain. The numbers presented in HBAI are therefore all subject to sampling error, because they have been calculated based on a sample of families, and not based on information on all families in Great Britain.

If we ignore issues of statistical precision, we will judge the government to have met its target of 'reducing the number of children in poverty by at least a quarter [of its level in 1998-99] by 2004' if HBAI gives a level of child poverty of 3.1 million or fewer, and to have failed otherwise.

However, the government estimates that the standard error on the number of children in poverty is around $66,000 .{ }^{19}$ This means that if HBAI estimates child

\footnotetext{
${ }^{18}$ The latest of which is Department for Work and Pensions, Households Below Average Income 1994/5 to 2001/02, CDS, Leeds, 2003.

${ }^{19}$ Appendix 2 in Department for Work and Pensions, Households Below Average Income $1994 / 5$ to $2001 / 02$, op. cit., says that the $95 \%$ confidence interval is $+/-130,000$, implying a standard error of 66,326 .
} 
poverty to be 3.1 million or 3.2 million in 2004-05, we would not be able to tell for certain whether the target had been met. For example, it could be (correctly) argued that an estimated child poverty level of 3.2 million in HBAI is not statistically different from 3.1 million, and therefore consistent with the target being met. Similarly, if HBAI showed that child poverty fell to 3.1 million, this could be argued to be not statistically different from 3.2 million, and therefore consistent with the target not being met. ${ }^{20}$

We present this discussion not because we seriously think that the government will appeal to sampling error if it appears to miss its target for 2004-05 narrowly (nor because we expect that the government's critics will appeal to sampling error if the government appears to meet its target), but to emphasise the point that care needs to be taken when making inferences based on estimated differences in child poverty of less than 150,000. Given the possibility of sampling and other errors, it is certainly possible that the government could hit its 2004-05 target without increasing the per-child element of the tax credit by $£ 3$ a week. Equally, it could implement the increase and still end up missing the target. But uncertainty does not absolve policymakers of the need to make policy, and our best judgement remains that a $£ 3$-a-week increase is necessary to make achievement of the target by a narrow margin the most likely outcome.

\section{Child poverty beyond 2004-05}

The government is still deciding what definition of child poverty it wishes to target in the longer term. ${ }^{21}$ If the government wishes to reduce child poverty further measured under its current definition, then, in the absence of helpful economic or demographic changes (such as more parents working), it will probably have to increase the child tax credit faster than median income grows. This is because the child tax credit provides only part of the incomes of the poorest households with children.

\footnotetext{
${ }^{20}$ Further complexities would arise if the government redefined its target to be 'to reduce child poverty by $1,050,000$ from its $1998-99$ level by $2004-05^{\prime}$. Although this implies the same target of 3.15 million in 2004-05, the standard error on estimates of the change in child poverty is about 93,000 , and so a decline in child poverty of 900,000 (i.e. a level of child poverty of 3.3 million) would not be statistically different from a decline of 1,050,000 (the standard error on the change in child poverty is larger than the standard error on the levels of child poverty because each year of HBAI is a different, independent, sample; if the standard error on the level is 66,000 , then the standard error on the change is $\sqrt{2} \times 66,000 \approx 93,000$ ). Yet another calculation would be required if the target were interpreted as 'child poverty should fall by a quarter'.

${ }^{21}$ The government is due to announce by the end of this year how we might tell whether poverty has been eradicated in 2020 and what measure of poverty is due to be halved by 2010, following a long consultation (see Department for Work and Pensions, Measuring Child Poverty: A Consultation Document, London, 2002, www.dwp.gov.uk/consultations/consult/2002/childpov/childpoverty.pdf).
} 
In fact, our data-set suggests that the child tax credit will comprise around half of the disposable income of households with children in poverty in 2004, with other important income sources being other means-tested benefits, other tax credits, net earnings and maintenance. In order for child poverty to remain constant, the total income of poor families with children needs to rise in line with median income, in the absence of helpful economic or demographic changes. If any of the income sources of families with children grow more slowly than median income - as has been the case for income support personal allowances since 1988 - then the child tax credit will need to grow faster than median income.

Halving child poverty would require even larger increases. For example, our model suggests that if the per-child element of the child tax credit (and the allowances and premiums in housing benefit and council tax benefit) were increased by $£ 12$ a week in April 2004, then child poverty might fall to around 2 million next year, broadly half its level when the Chancellor first stated the ambition to halve child poverty. This reform would cost a substantial $£ 5.5$ billion, representing an increase of around a quarter in the annual total value of government financial support for parents. ${ }^{22}$ It would imply that the poorest families with children would receive $£ 3,420$ a year in child-contingent support if they had one child, and $£ 6,080$ a year if they had two children. Of course, the amount of child tax credit received by the poorest families with children would still need to be increased at least as fast as median income for the next six years for the fall in child poverty to be maintained until 2010 .

This discussion is not intended to provide a sensible estimate of what it would cost to halve child poverty if the government maintained its current favoured definition. The government does not rely on the child tax credit alone to increase the incomes of poor families with children, and the trend towards higher employment rates amongst parents should also help reduce child poverty further. But it is certainly the case that achieving a society where 2 million children live in households with incomes below $60 \%$ of the median would require an enormous change in the income distribution of families with children.

There is also a risk that continuing to target a poverty measure defined exclusively in terms of incomes will skew the policy response excessively towards tax credit and benefit increases for parents, and away from improving public services for children. By way of example, the extra spending that we think is needed for the government to meet its target for 2004-05 would pay for the Sure Start programme - which provides help to children under 5 and their

\footnotetext{
${ }^{22}$ S. Adam, M. Brewer and H. Reed, The Benefits of Parenting: Government Financial Support for Families with Children Since 1975, IFS Commentary 91, London, 2002, estimates that the government will spend $£ 21$ billion on child-contingent financial support to parents in 2003.
} 
parents in disadvantaged areas - to be doubled in size, and increasing the perchild element of the child tax credit by $£ 3$ a week would cost double what is currently spent on early years education, childcare and Sure Start. ${ }^{23}$ However, research cannot yet tell us whether directing extra resources to parents is better for children's well-being in the longer term than improving services for children.

\footnotetext{
${ }^{23}$ The budget for early years education, childcare and Sure Start was $£ 2.9$ billion in 2003-04, $£ 0.5$ billion of which was for Sure Start; see The Number 10 Strategy Unit, Inter-

Departmental Childcare Review - November 2002, Delivering for Children and Families, 2002, http://www.number-10.gov.uk/su/childcare/index.htm.
} 